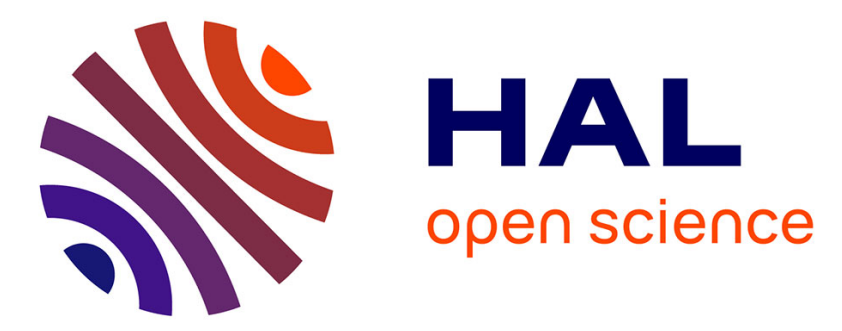

\title{
Investigation of the acclimatization period: example of the microbial aerobic degradation of volatile organic compounds (VOCs)
}

Sandrine Bayle, Luc Malhautier, Valérie Degrange, Jean-Jacques Godon, Jean-Louis Fanlo

\section{To cite this version:}

Sandrine Bayle, Luc Malhautier, Valérie Degrange, Jean-Jacques Godon, Jean-Louis Fanlo. Investigation of the acclimatization period: example of the microbial aerobic degradation of volatile organic compounds (VOCs). Water Science and Technology, 2009, 60 (9), pp.2217-2225. 10.2166/wst.2009.653 . halsde-00525255

\section{HAL Id: halsde-00525255 \\ https://hal.science/halsde-00525255}

Submitted on 26 May 2021

HAL is a multi-disciplinary open access archive for the deposit and dissemination of scientific research documents, whether they are published or not. The documents may come from teaching and research institutions in France or abroad, or from public or private research centers.
L'archive ouverte pluridisciplinaire HAL, est destinée au dépôt et à la diffusion de documents scientifiques de niveau recherche, publiés ou non, émanant des établissements d'enseignement et de recherche français ou étrangers, des laboratoires publics ou privés. 


\title{
Investigation of the acclimatization period: example of the microbial aerobic degradation of volatile organic compounds (VOCs)
}

\author{
Sandrine Bayle, Luc Malhautier, Valérie Degrange, Jean-Jacques Godon \\ and Jean-Louis Fanlo
}

\begin{abstract}
$\overline{\text { ABSTRACT }}$
The aim of this study is to better evaluate the occurrence of an acclimatization-enrichment period, defined as a selection period of consortia having the capability to biodegrade pollutants. In order to perform this evaluation, two experimental strategies were carried out and the results were studied carefully. Two laboratory-scale reactors were inoculated with activated sludge from an urban treatment plant. During the experiment, these reactors were supplied with a gaseous effluent containing VOCs. For both reactors, the composition is different. Three parameters were monitored to characterize the microflora: bacterial activities, bacterial densities, and the genetic structure of Bacteria and Eukarya domains (Single Strand Conformation Polymorphism fingerprint). The obtained results showed that the resultant biodegradation functions were equivalent. The bacterial community structure differs even if six co-migrated peaks were observed. These data suggest that the microbial communities in both reactors were altered differently in response to the treatment but developed a similar capacity to remove vOCs at the issue of this period. Furthermore, it is suggested that the experimental strategies developed in this work lead to an enrichment in terms of functionality and microbial diversity almost equivalent.

Key words | acclimatization, biological treatment, enrichment, microbial diversity, performance, VOCS
\end{abstract}

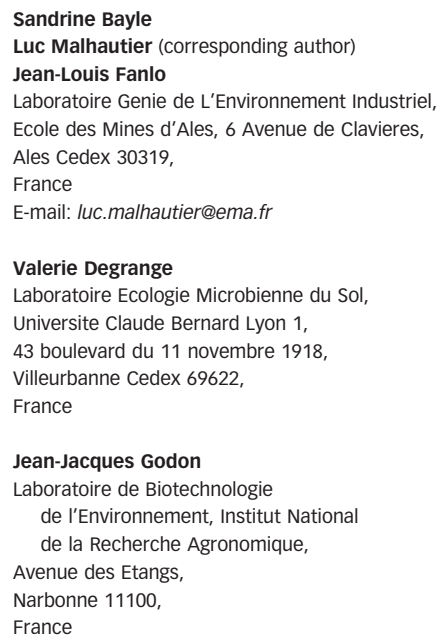

\section{INTRODUCTION}

In ecology, "acclimatization" is defined as the habituation of an organism's physiological response to environmental conditions (usually applied to laboratory environments) (Townsend et al. 2002). Nevertheless, this term has been widely used and, in particular areas, is commonly applied to both the acclimatization and the enrichment steps. The enrichment period corresponds to the selection, from a complex ecosystem, of microorganisms that are already present and are capable of growth and carrying out specific reactions (Madigan et al. 1997). Few authors have studied the acclimatization period, dealing with the degradation of chemicals. Linkfield et al. (1989) characterized the lag period before anaerobic dehalogenation of halobenzoates. The lengthy acclimatization period appears to represent an enzyme induction phase in which little or no aryl dehalogenation is observed, followed by an exponential increase in activity typical of an enrichment response. Lewis et al. (1986) determined adaptation lag periods for the microbial transformation of $p$-cresol and showed that adaptation lag periods for the microbial transformation of low concentrations of chemicals may correlate with limiting nutrient concentrations. 
For other authors, the distinction between acclimatization and enrichment remains unclear. Pessione et al. (I996) showed that a strain of Acinetobacter radioresistens was able to utilize phenol as the only carbon and energy source, after an acclimatization period of 3 days in which increasing phenol concentrations from 50 to $200 \mathrm{mgL}^{1}$ were supplied. Moreno-Andrade \& Buitron (2004) studied the variation of microbial activity during acclimatization to 4-chlorophenol (4CP) in an aerobic automated sequencing batch reactor. The results show a reduction in degradation time as the acclimatization process occurred and this reduction is linked to the initial concentration of $4 \mathrm{CP}$. The authors also showed that, as acclimation took place, the capability of the consortia to biodegrade the toxic increased. Rhine et al. (2003) evaluated microbial community responses to atrazine exposure and nutrient availability. The authors showed that repeated pesticide exposure may enhance biodegradation through selective enrichment of pesticide-metabolizing microorganisms, particularly when the compound is used as a carbon and energy source. For the treatment of gaseous effluents containing Volatile Organic Compounds (VOCs), an acclimatization period may be carried out before inoculating the bioreactor. It consists in forcing a gaseous effluent containing the VOCs through the suspension of activated sludge. This favors the selection of microbial communities with the ability to remove VOCs (Devinny et al. 1999). Tellez et al. (2002) evaluated the operational performance and petroleumhydrocarbon-removal efficiency of an activated sludge treatment system from oilfield-produced water. The authors initiated an aggressive acclimatization procedure to build the microbial concentration to levels that would achieve effective hydrocarbon removal efficiencies.

It remains difficult to distinguish acclimatization from enrichment and furthermore to know whether a complex mix of acclimatization and enrichment or enrichment only occurs. The aim of this study is therefore to better evaluate the occurrence of this acclimatizationenrichment period. In order to perform this evaluation, two different experimental strategies have been performed and the results have been studied carefully. We considered the biological degradation of chemicals because the results obtained would provide answers to the question. Moreover, microbial biodegradation is one of the most important factors affecting the concentration of chemicals in nature.

In order to check whether acclimatization-enrichment period occurs, the performance of two systems was studied by using two reactors filled with an identical activated sludge suspension but using two different feeding methods. One reactor was supplied with an effluent containing a complex VOC mixture (oxygenated, aromatic and halogenated compounds) for which the concentration of oxygenated compounds varied with incubation time. The other was supplied with an effluent gradually enriched with chlorinated, aromatic and oxygenated compounds. As VOCs concentrations increase, a complex mix of acclimatization to higher concentrations and the selection for bacteria able to grow faster can be suggested. Microbial communities were considered, and more specifically biodegradation activities and genetic structuring.

\section{MATERIALS AND METHODS}

\section{Chemical reagents}

The complex VOC mixture, used in this study, contained 11 compounds (Carlo Erba Reagenti, 99\% puro), belonging to different chemical groups:

- Oxygenated compounds: methanol, acetone, methyl ethyl ketone (MEK), methyl isobutyl ketone (MIBK), butyl and ethyl acetates.

- Aromatic compounds: toluene, ethylbenzene (EB), p-xylene.

- Chlorinated aliphatic compounds: dichloromethane (DCM) and 1,2-dichloroethane (DCE).

The mixtures of VOCs were prepared by mixing liquid masses of the different compounds.

\section{Reactor design}

Two pilot-scale units, called " $\mathrm{C}$ " and "S", were used in this study (Figure 1). The liquid VOC mixture was continuously injected and vaporized into a filtered air stream operating at $10 \mathrm{Lmin}^{1}$ via a Precidor syringe pump (Infors AG, Switzerland). Some of the polluted air $\left(1 \mathrm{Lmin}^{1}\right)$ 


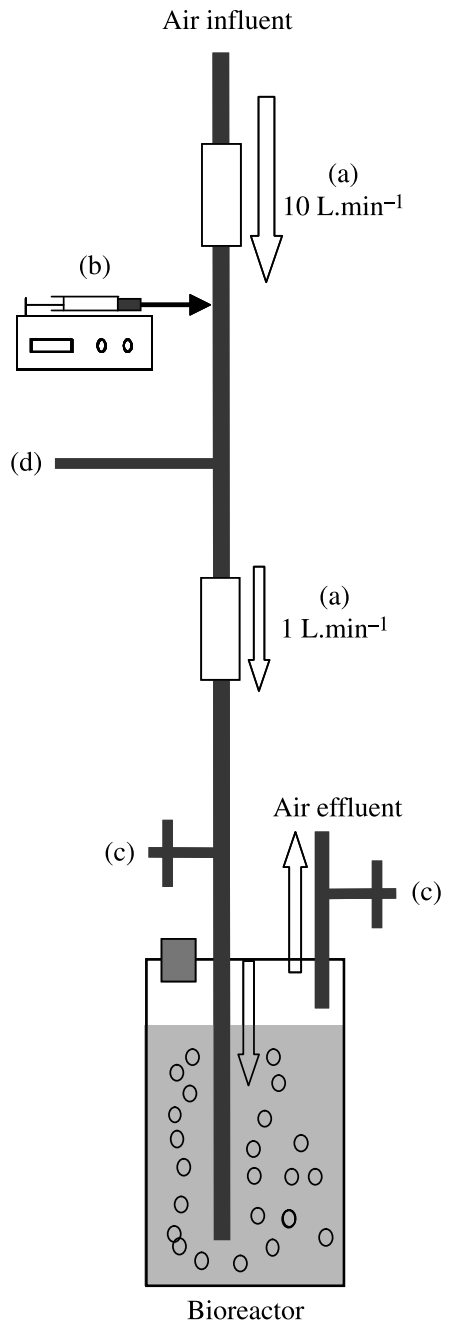

Figure 1 | Pilot scale unit. (a): flow rate regulators; (b): syringe pump loaded with the mixture of VOCs; (c): gas sampling; (d): gas split.

was forced through a $5 \mathrm{~L}$ glass reactor seeded with $4 \mathrm{~L}$ of activated sludge. The Empty Bed Residence Time was $4 \mathrm{~min}$. The composition of the activated sludge was $4.5 \mathrm{~g}$ of chemical oxygen demand $\mathrm{L}^{1}, 1.1 \mathrm{~g}$ of biological oxygen demand $\mathrm{L}^{1}$, and $5.2 \mathrm{~g}$ of total suspended solids $\mathrm{L}^{1}$. Activated sludge came from the domestic sewage treatment plant of Saint Christol lez Alès (France) (6,500 populationequivalent). The loading was as follows: $860 \mathrm{mg}$ of chemical oxygen demand $\mathrm{L}^{1}$ day ${ }^{1}, 340 \mathrm{mg}$ of biological oxygen demand $\mathrm{L}^{1}$ day ${ }^{1}$, and $380 \mathrm{mg}$ of total suspended solids L ${ }^{1}$ day ${ }^{1}$. The Volatile Suspended Solids (VSS) were around $80 \%$. The sludge age was around 10 days.

The volume of sludge was maintained constant by the daily addition of a mineral salt nutrient solution, HCMM3, as developed by Juteau et al. (1999). The experiment was performed at normal room temperature $\left(20-25^{\circ} \mathrm{C}\right)$ for 117 days. Neutral $\mathrm{pH}$ was daily maintained using a $\mathrm{NaOH}$ solution (1 M).

\section{Composition of the inlet gas}

The gaseous influent composition is given in Table 1. Two periods need to be distinguished.

From the beginning of the experiment to $t=66$ days (Period 1), the composition of the polluted gas supplying each reactor was different. The gaseous influent supplying reactor S contained firstly chlorinated compounds only (from the beginning to $t=37$ days), then a mixture of chlorinated and aromatic compounds from $t=39$ days to $t=66$ days (Table 1$)$.

The concentrations of aromatic and chlorinated compounds were 2.1 and $1.4 \mathrm{~g} \mathrm{~m}^{3}$ respectively. During period 1 , reactor $\mathrm{C}$ was supplied with a gaseous influent containing all the chemical groups of VOCs, that is to say oxygenated, aromatic and chlorinated compounds. The concentrations of aromatic and chlorinated compounds were 2.1 and $1.4 \mathrm{~g} \mathrm{~m}^{3}$ respectively. The concentration of oxygenated compounds decreased as follows: It was $4.2 \mathrm{~g} \mathrm{~m}^{3}$ from the beginning to $t=37$ days $\left(0.7 \mathrm{~g} \mathrm{~m}^{3}\right.$ for each compound), then $2.35 \mathrm{~g} \mathrm{~m}^{3}$ from $t=38$ days to $t=66$ days $\left(0.4 \mathrm{~g} \mathrm{~m}^{3}\right.$ for each compound). The composition of the oxygenated compounds mixture supplied to the reactors through the experiments is the same.

During the second period (period 2), both reactors were supplied with a polluted gas of identical composition (Table 1). The gaseous influent contained a complex mixture of chlorinated, aromatic and oxygenated compounds from $t=67$ days to the end of the experiment. The concentrations of aromatic and chlorinated compounds were 2.1 and $1.4 \mathrm{~g} \mathrm{~m}^{3}$ respectively. The concentration of oxygenated compounds was $0.84 \mathrm{~g} \mathrm{~m}^{3}$ from $t=67$ days to $t=82$ days $\left(0.14 \mathrm{~g} \mathrm{~m}^{3}\right.$ for each compound), then $2.1 \mathrm{~g} \mathrm{~m}^{3}$ from $t=83$ to $t=96$ days ( $0.35 \mathrm{~g} \mathrm{~m}^{3}$ for each compound) and finally $4.2 \mathrm{~g} \mathrm{~m}^{3}$ from $t=97$ to $t=117$ days $\left(0.7 \mathrm{~g} \mathrm{~m}^{3}\right.$ for each compound). The composition of the oxygenated compounds mixture supplied to the reactors through the experiments was the same. 
Table 1 | Composition of the polluted gas with increasing incubation time

\begin{tabular}{|c|c|c|c|c|c|c|}
\hline \multirow[b]{2}{*}{ Time (day) } & \multicolumn{2}{|c|}{ Oxygenated compounds (g.m ${ }^{3}$ ) } & \multicolumn{2}{|c|}{ Aromatic compounds (g.m ${ }^{3}$ ) } & \multicolumn{2}{|c|}{ Halogenated compounds (g.m ${ }^{3}$ ) } \\
\hline & Reactor C & Reactor S & Reactor C & Reactor S & Reactor C & Reactor S \\
\hline \multicolumn{7}{|l|}{ Period 1} \\
\hline 137 & 4.2 & 0 & 2.1 & 0 & 1.4 & 1.4 \\
\hline 3866 & 2.35 & 0 & 2.1 & 2.1 & 1.4 & 1.4 \\
\hline \multicolumn{7}{|l|}{ Period 2} \\
\hline 6782 & 0.84 & 0.84 & 2.1 & 2.1 & 1.4 & 1.4 \\
\hline 8396 & 2.1 & 2.1 & 2.1 & 2.1 & 1.4 & 1.4 \\
\hline $97 \quad 117$ & 4.2 & 4.2 & 2.1 & 2.1 & 1.4 & 1.4 \\
\hline
\end{tabular}

The composition of gaseous effluent was modified after removal efficiency had been maintained for a minimal period of three days.

\section{Biodegradation monitoring}

The biodegradation of VOCs was measured daily by monitoring the concentration of each compound at the sampling inlets and outlets. The reactor sampling ports were directly connected, via Teflon tubes, to a gas chromatograph unit (HP 6890, Hewlett Packard) equipped with a flame ionization detector. A 30-metre HP-1 capillary column was used with a carrier gas (Helium) flow rate of $2.5 \mathrm{~mL}$. min ${ }^{1}$. The gas sample was injected into the column via an automatic gas sampling valve $(250 \mu \mathrm{L})$ : the gas samples were thus not stored. The temperature of injector and detector were 150 and $220^{\circ} \mathrm{C}$ respectively. For the detector, the air flow rate was $310 \mathrm{ml} \mathrm{min}{ }^{1}$, the hydrogen flow rate was $46.5 \mathrm{ml} \mathrm{min}^{1}$ and the helium flow rate was $30 \mathrm{ml}$ $\min { }^{1}$. The temperature ramp was as follows. At the beginning, the temperature of the oven was $40^{\circ} \mathrm{C}$ for one minute, then it was increased from 40 to $90^{\circ} \mathrm{C}$ at $15^{\circ} \mathrm{C}$ per min. The temperature was then maintained stable at $90^{\circ} \mathrm{C}$ for $4 \mathrm{~min}$ and finally increased to $150^{\circ} \mathrm{C}$ at $10^{\circ} \mathrm{C}$ per min.

The biodegradation was monitored by calculating the VOC removal efficiency (RE) as follows:

$R E=\frac{C i \quad C o}{C i} \times 100$

RE: Removal Efficiency (\%); Ci: Inlet concentration of VOCs $\left(\mathrm{gm}^{3}\right)$; Co: Outlet concentration of VOCs $\left(\mathrm{g} \mathrm{m}^{3}\right)$.

The error in the VOC concentration measurement was evaluated using an empty reactor. The pollutant concentration was determined 9 times, enabling the Relative Standard Deviation (RSD) to be estimated at 10\%.

\section{Bacterial enumeration}

Bacteria were enumerated by fluorescence microscopy using staining with DAPI (4',6-diamidino-2-phenylindole, Sigma, USA) to determine the total bacteria number (Kepner \& Pratt I994).

A volume of sample $(2 \mathrm{ml})$ was diluted in 9 volumes of $1 \%$ sodium hexametaphosphate, and homogenized using a blender (Ultra Turax, T25 basic, IKA) for $2 \mathrm{~min}$ at $19,000 \mathrm{rpm}$. Then, $1 \mathrm{~mL}$ of this suspension was incubated with $3.7 \%$ formaldehyde for $30 \mathrm{~min}$, before counter- staining by DAPI at a final concentration of $20 \mu \mathrm{g} \mathrm{mL}{ }^{1}$ for $1 \mathrm{~h}$, in the dark, at an agitation speed of $200 \mathrm{rpm}$.

Stained bacteria were recovered on a $0.2 \mu \mathrm{m}$-polycarbonate membrane filter (Millipore GTBP, Ireland) by microfiltration. The filters were then mounted on microscope slides in Mounting Medium (Sigma, USA) and observed using an epifluorescence microscope (DMLB, Leica, Germany) equipped with a blue excitation filter (BP 340-380 nm) and an LP 425 barrier filter. For each slide, 30 fields were counted and the Relative Standard Deviation (RSD) was calculated for each count.

\section{Analysis of total DNA by PCR-SSCP}

The DNA extraction method has been described in a previous work (Godon et al. 1997). The target DNA amplified was the V3 region of the $16 \mathrm{~S}$ rDNA gene for the bacteria domain (primers W104 and W049) (Table 2), 


\begin{tabular}{|c|c|c|}
\hline Name & Sequence & Position \\
\hline W104 & $5^{\prime} 6$ Fam TTACCGCGGCTGCTGGCAC $3^{\prime}$ & R533 \\
\hline W049 & $5^{\prime}$ ACGGTCCAGACTCCTACGGG 3' & F331 \\
\hline W131 & $5^{\prime} 6$ Fam GGGCATCACAGACCTGTT $3^{\prime}$ & R1195 \\
\hline W16 & $5^{\prime}$ CTTAATTGACTCAACACGG $3^{\prime}$ & F2600 \\
\hline
\end{tabular}

positions were defined by the $E$. coli sequence.

and a region of the 18S rDNA gene for the eucarya domain (primers W16 and W131) (Table 2). Primers W104 and W131 were labeled by a 6-FAM fluorochrome. Each reaction tube contained $100 \mathrm{ng}$ of each primer, $10 \mathrm{mM}$ dNTPs, 1X Pfu Turbo DNA polymerase reaction buffer with $25 \mathrm{mM} \mathrm{MgCl}, 1.25 \mathrm{U}$ Pfu Turbo DNA polymerase (Stratagene) and $1 \mu \mathrm{L}$ of purified template DNA adjusted to a total volume of $50 \mu \mathrm{L}$.

The reaction mixtures were placed in a thermocycler (Perkin Elmer) at $94^{\circ} \mathrm{C}$ for $30 \mathrm{~s}$. Three-stage cycles were then performed 30 times: at $94^{\circ} \mathrm{C}$ for $30 \mathrm{~s}$, at $51^{\circ} \mathrm{C}$ for primers $\mathrm{W} 16 / \mathrm{W} 131$, and $61^{\circ} \mathrm{C}$ for $\mathrm{W} 104 / \mathrm{W} 049$ for $30 \mathrm{~s}$, $72^{\circ} \mathrm{C}$ for $30 \mathrm{~s}$, and a final stage at $72^{\circ} \mathrm{C}$ for $15 \mathrm{~min}$.

The PCR products were diluted depending on the band intensity on $2 \%$ agarose gel. $1 \mu \mathrm{L}$ of diluted PCR products was mixed with $18.8 \mu \mathrm{L}$ of loading buffer TSR (Applied Biosystem) and $0.2 \mu \mathrm{L}$ of internal weight standard Genescan-400 HD Rox (Applied Biosystem). The double-strand helix was then separated for $2 \mathrm{~min}$ at $94^{\circ} \mathrm{C}$, and immediately cooled in an ice-water bath for $10 \mathrm{~min}$, ensuring that singlestranded products were obtained. Capillary electrophoresis S.S.C.P analysis was performed on an ABI PRISM 310 automated DNA sequencer (Applied Biosystem) equipped with a capillary tube filled with a polymer, for $30 \mathrm{~min}$ at $12 \mathrm{KV}$ and $32^{\circ} \mathrm{C}$. A sample volume of $5 \mu \mathrm{L}$ was loaded onto the polymer [Genescan polymer $(7 \% \mathrm{w} / \mathrm{w})$ at $8 \mathrm{mg} / \mathrm{mL}$, Glycerol 10\%, TBE 1X].

The SSCP profiles were compared after alignment with the internal weight standard.

The SSCP profiles were first analyzed by visual comparison, then using the SSCP2 software developed in the Environmental Biotechnology Laboratory, Narbonne, France. This software determines and aligns peaks; so co-migrated peaks were recognized.

\section{$\overline{\text { RESULTS }}$}

The microbial aerobic degradation of a complex mixture of VOCs was investigated. Two bioreactors were used and inoculated with activated sludge coming from an urban wastewater treatment plant. Pollutant removal, bacterial densities and the dynamics of microbial diversity were determined for increasing incubation time. The occurrence of an acclimatization-enrichment period was evaluated (from $t=67$ to $t=117$ day).

\section{Pollutant removal}

The removal efficiency for VOCs at $t=66$ days is summarized in Table 3.

For reactor $\mathrm{S}$, the removal efficiency of ethylbenzene was $70 \%$, the removal efficiency of toluene and p-xylene was $40 \%$. For reactor C, esters were completely eliminated, the removal efficiency of MEK was 50\%, methanol, acetone and MIBK were not eliminated. From $t=70$ days to the end of the experiment (Figure 2), it was observed that the VOC removal efficiency became equivalent for the two reactors.

Chlorinated compounds were not eliminated in either reactor. Aromatics were degraded only in reactor S, and their abatement decreased progressively from $50 \%$ at $t=66$ days to $0 \%$ at $t=82$ days when the concentration of oxygenated compounds was increased from 0 to $140 \mathrm{mg} \mathrm{m}^{3}$. The removal of oxygenated compounds against increasing incubation period is shown in Table 4.

\begin{tabular}{lll} 
Table 3 | Elimination efficiency (\%) reached for Voc chemical groups at $t$ & 66 days \\
Compounds & Reactor s & Reactor C \\
\hline $\begin{array}{l}\text { Oxygenated } \\
\text { Esters }\end{array}$ & - & 42 \\
Acetone Methanol MIBK & & 100 \\
MEK & & NR \\
Aromatics & 50 & 50 \\
$\quad$ Ethylbenzene & 70 & NR \\
Toluene & 40 & \\
$\quad$ p Xylene & 40 & \\
Chlorinated & NR & NR
\end{tabular}

NR: Not Removed; _ not supplied; the Relative Standard Deviation (RSD) was estimated at $10 \%$. 


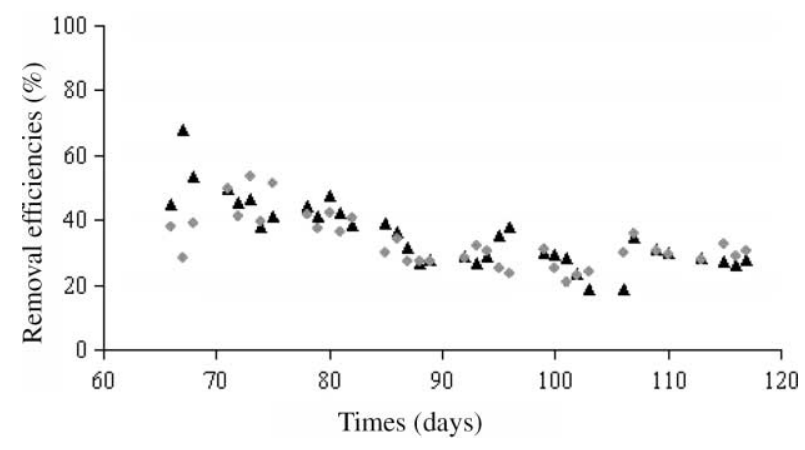

Figure 2 | VOCs removal efficiency (\%) reached for reactors S and C from the 66th to the 117th day. Reactor $\mathrm{C}$ and $\boldsymbol{\Delta}$ Reactor S.

The removal efficiency measured for ketones, esters and methanol differs. The esters were completely removed. The removal efficiency for other molecules decreased. Acetone and MIBK were poorly eliminated from the 83rd to the 117 th day period. The removal efficiency of methanol and MEK respectively ranged from 35 to 49 and 100 to 36\% for reactor $\mathrm{C}$ and 75 to 57 and 75 to $31 \%$ for reactor S. Hence, the evolution of the removal of oxygenated compounds was generally similar for both reactors (Table 4).

\section{Densities and diversity}

The total bacterial densities increased from $(3.1 \pm 0.7) \times 10^{8}$ cells $\mathrm{mL}^{1}$ at $t=0$ day to $(1.9 \pm 0.3) \times 10^{9}$ cells $\mathrm{mL}{ }^{1}$ for reactor $\mathrm{C}$ and $(6.2 \pm 0.5) \times 10^{8}$ cells $\mathrm{mL}^{1}$ for reactor $\mathrm{S}$ at $t=66$ days (Figure 3 ). Between $t=66$ and $t=117$ days, the bacterial densities were stable in both reactors, with $(1.9 \pm 0.3) \times 10^{9}$ cells $\mathrm{mL}^{1}$ for reactor $\mathrm{C}$ and $(7.0 \pm 0.5) \times 10^{8}$ cells $\mathrm{mL}^{1}$ for reactor $\mathrm{S}$. The microbial community structure was observed for the Bacteria and Eukarya phylogenetic domains using SSCP analysis. Figure 3 shows the bacterial community structure against increasing incubation time. The diversity of the total

Table 4 | Oxygenated compound removal efficiency (\%) with incubation time for $t 66$ to $t 117$ days in both reactors

\begin{tabular}{llllrlrlrl} 
Reactor & C & S & C & S & C & S & C & S \\
Time (d) & Esters & & \multicolumn{3}{c}{$\begin{array}{l}\text { Acetone- } \\
\text { MIBK }\end{array}$} & Methanol & MEK & \\
\hline 66 & 82 & 100 & 100 & 36 & 32 & 35 & 75 & 100 & 75 \\
83 & 96 & 100 & 100 & 14 & NR & 41 & 66 & 35 & 57 \\
97 & 117 & 100 & 100 & 16 & 11 & 49 & 57 & 36 & 31 \\
\hline
\end{tabular}

The average elimination efficiency (\%) is indicated; NR: Not removed.

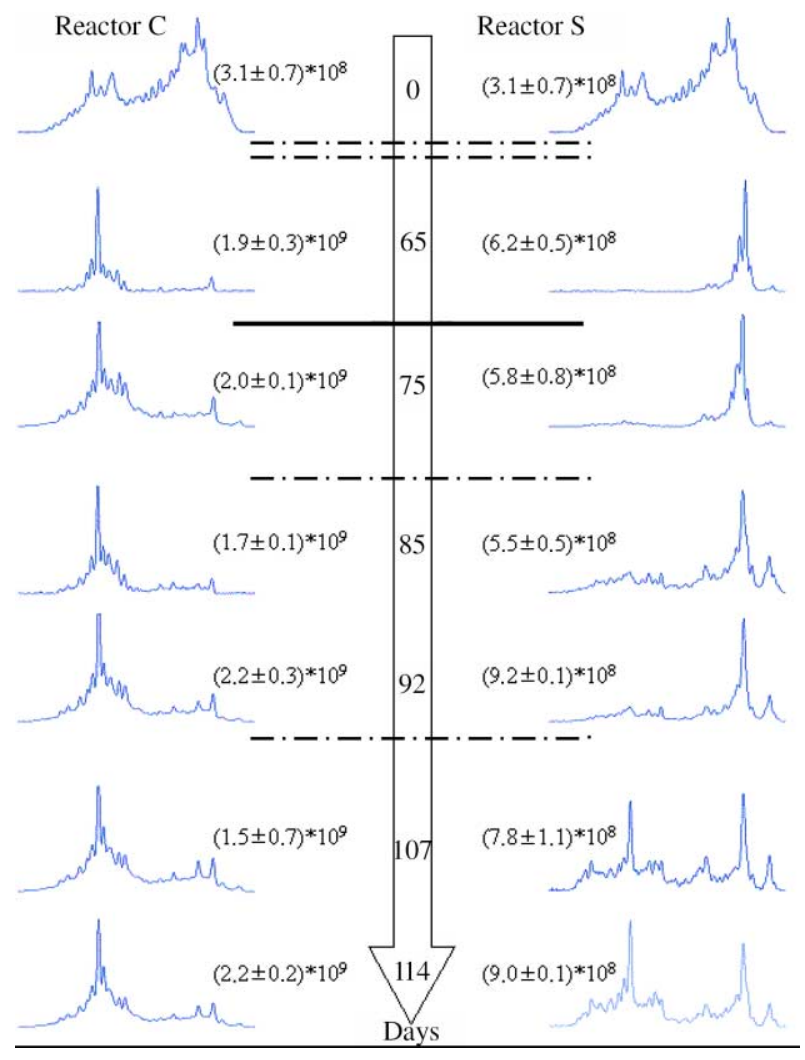

Figure 3 | Bacterial community dynamics for reactors S and C: total bacteria densities and genetic structure of total bacterial communities. $X$ axis: time; $Y$ axis: peak area.

bacterial community coming from activated sludge at the beginning of the experiment $(t=0)$ shows a wide range. SSCP profile analysis reveals 25 peaks. Between $t=0$ to $t=67$ days, the number of peaks decreases. For reactor $\mathrm{C}$, there are some peaks on the left of the pattern (approximately 10 peaks, of which one is dominant) while for reactor $\mathrm{S}$, the peaks are located on the right of the pattern (approximately 7 peaks, of which one is dominant).

For reactor $\mathrm{C}$, between $t=67$ and $t=117$ days, the patterns do not show any major variations with increasing incubation time. The dominant peaks are located on the left of the pattern throughout the duration of the experiment. For reactor $\mathrm{S}$, between $t=67$ and $t=117$ days, the patterns were modified with increasing incubation time. The peaks are firstly largely located on the right of the profile. Nevertheless, other peaks located on the left are also observed. At $t=114$ days, 2 peaks are dominant, and are located at the pattern ends. 

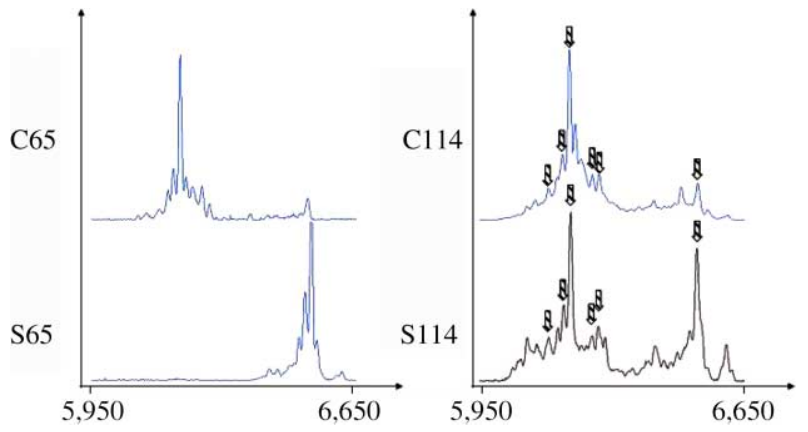

Figure 4 Comparison of the bacterial communities at $t \quad 65$ and at $t \quad 114$ days for reactors $\mathrm{S}$ and $\mathrm{C} \mathbb{}$ : co migrated peaks. $\mathrm{X}$ axis: time; $\mathrm{Y}$ axis: peak area.

The comparison of the bacterial community picture for reactors $\mathrm{C}$ and $\mathrm{S}$ at $t=65$ and $t=114$ days is shown in Figure 4. The comparison of the profiles obtained at $t=65$ days shows that no peak co-migrates. The comparison of the bacterial pattern at the end of the experiment shows that six prominent peaks co-migrate.

The diversity is lower for Eukarya than for Bacteria. Only six peaks are present at the beginning of the experiment (Figure 5). For reactor C, at $t=40$ days, the diversity is modified and the dominant peak is located further on the left than observed at $t=0$ day. Between $t=71$ and $t=117$ days, the patterns are similar. At $t=114$
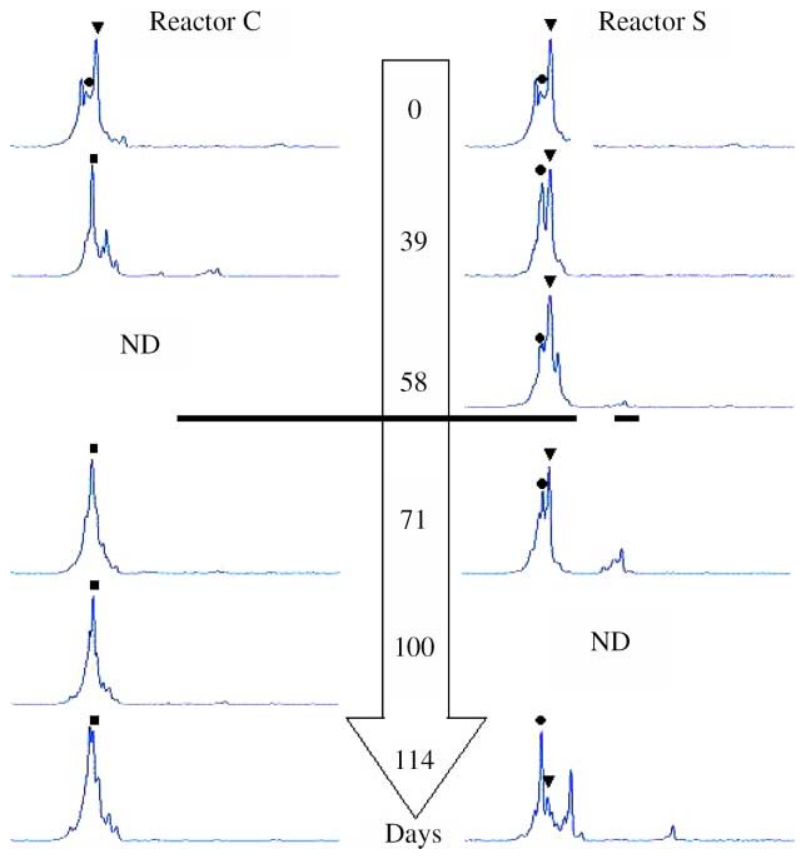

Figure 5 Evolution of the Eukarya domain diversity with increasing incubation time in reactors S and C. ND: no amplification of 16S DNA was obtained for the considered day. $\mathrm{X}$ axis: time; $\mathrm{Y}$ axis: peak area. days, six peaks are counted, as on the $t=40$ days profile. The new peak $\square$ becomes dominant from $t=39$ days. For reactor $\mathrm{S}$, the profiles are different for each analysis. The number of peaks varies and increases from two (at $t=40$ days) and three (at $t=58$ days) to ten peaks at $t=114$ days. Peaks and $\boldsymbol{\nabla}$ are present throughout the duration of the experiment. They dominate the pattern (Figure 5). Superposition of the profiles at the end of the experiment shows distinct bacterial communities in the two reactors.

\section{$\overline{\text { DISCUSSION }}$}

Two experimental strategies were carefully applied in the laboratory in order to better assess whether acclimatization-enrichment period occurred. The results of these experiments were analyzed to check for the occurrence of acclimatization-enrichment.

Firstly, at $t=64$ days, it was observed that the VOC mixture led to a decrease in bacterial diversity. This phenomenon has already been observed in soil and sediment studies after the microflora has been contaminated with pollutants such as mercury (Rasmussen \& Sørensen 200I), fuel (Stephen et al. 1999) or polycyclic aromatic hydrocarbons (Langworthy et al. 1998), and during the start-up phase of bioreactors supplied with different pollutants, such as cattle manure (Chachkhiani et al. 2004) or aromatic compounds (Stoffels et al. I998). From $t=67$ to $t=114$ days, the obtained results (Table 4) show that the resulting biodegradation functions become similar. In both cases, the microbial community could not simultaneously remove all the compounds. The obtained results showed that the operating strategies applied did not lead to the selection of a bacterial community with enhanced biodegradation functions. Moreover, it was shown competitive phenomena between substrates and that oxygenated compounds were used first. Furthermore, the performance of both reactors subsequently became equivalent, whichever the strategy used. While the degradation efficiencies were equivalent for both reactors, the results obtained show that the bacterial community structure differs. Hence, the experimental strategies used lead to the same enrichment in terms of functionality, but different enrichments in terms of microbial diversity. Some authors have reported that 
some reactors can reach similar removal efficiencies and support different microbial consortia. The performances of biofilters which received three different inocula were compared (Devinny et al. 1999). Three similar biofilters packed with chipped wood mixed with mushroom compost were used to treat $\alpha$-pinene after inoculation using three different extracts from spent mushroom compost, activated sludge and pine forest soil. After an adaptation period, all the reactors performed equally well. Nevertheless, analysis of the microbial community by the fatty acid methyl ester method confirmed that the biofilter with inoculated activated sludge contained different microbial species than the other two. Other authors have underlined that while reactors reached a steady state in terms of performances, a shift in the microbial community having colonized these reactors was observed. This result has been shown for anaerobic reactors (Fernandez et al. I999; Zumstein et al. 2000) and activated sludge reactors (Kaewpipat \& Grady 2002). Furthermore, Fernandez et al. (I999) showed that metabolic differences among the dominant fermenters detected suggest that changes in carbon and electron flow occurred during the stable performance and indicate that an extremely dynamic community can maintain a stable ecosystem function.

As the volumetric load of oxygenated compounds increased, a shift in the bacterial community structure of reactor S was observed. The comparison of SSCP profiles for both reactors at $t=114$ day showed six dominant Operational Taxonomic Units (OTU) co-migrations. It has been suggested that when the environmental conditions are favorable to bacterial growth, a shift in the bacterial community structure occurs and some OTUs may become dominant. Hence, the large number and diversity of minority populations is likely to contribute significantly to this dynamic. A similar bacterial community structure could be observed if the monitoring of both reactors had been extended. A description of OTU would allow this result to be confirmed.

To conclude, these data suggest that the microbial communities in both reactors were altered differently in response to the treatment but developed a similar functional capacity to remove VOCs at the end of the treatment period. Furthermore, we suggest that the experimental strategies developed in this work lead to almost equivalent enrichment in terms of both functionality and microbial diversity. In terms of pollution removal, acclimatizationenrichment strategies used in this study seem to be useless as easily biodegradable compounds only are removed. To improve this period, other parameters have to be considered such as concentration of pollutant in the air. Further studies could be also realized by considering, in a first time, separately chemical families of compounds.

\section{ACKNOWLEDGEMENTS}

We are grateful to Murielle Avezac (Ecole des Mines d'Ales, Ales, France) and Valerie Bru (INRA Narbonne, France) for technical support.

\section{REFERENCES}

Chachkhiani, M., Dabert, P., Abzianidze, T., Partskhaladze, G., Tsiklauri, L., Dudauri, T. \& Godon, J. J. 2004 16S rDNA characterisation of bacterial and archaeal communities during start up of anaerobic thermophilic digestion of cattle manure. Bioresour. Technol. 93, 227232.

Devinny, J. S., Deshusses, M. A. \& Webster, T. S. 1999 Biofiltration for Air Pollution Control. Lewis Publishers CRC Press LLC, Florida, USA.

Fernandez, A., Huang, S., Seston, S., Xing, J., Hickey, R., Criddle, C. \& Tiedje, J. 1999 How stable is stable? function versus community composition. Appl. Environ. Microbiol. 65, 36973704 .

Godon, J. J., Zumstein, E., Dabert, P., Habouzit, F. \& Moletta, R. 1997 Molecular microbial diversity of an anaerobic digestor as determined by small subunit rDNA sequence analysis. Appl. Environ. Microbiol. 63, 28022813.

Juteau, P., Larocque, R., Rho, D. \& LaDuy, A. I999 Analysis of the relative abundance of different types of bacteria capable of toluene degradation in a compost biofilter. Appl. Microbiol. Biotechnol. 52, 863868.

Kaewpipat, K., and Grady, C. P. L. Jr. 2002 Microbial population dynamics in laboratory scale activated sludge reactors. Water Sci. Technol. 46(1 2), 1927.

Kepner, R. L. J. \& Pratt, J. R. 1994 Use of fluorochromes for direct enumeration of total bacteria in environmental samples: past and present. Microbiol. Rev. 58, 603615.

Langworthy, D. E., Stapleton, R. D., Sayler, G. S. \& Findlay, R. H. I998 Genotypic and phenotypic responses of a riverine microbial community to polycyclic aromatic hydrocarbon contamination. Appl. Environ. Microbiol. 64, 34223428.

Lewis, D. L., Kollig, H. P. \& Hodson, R. E. 1986 Nutrient limitation and adaptation of microbial populations to chemical transformations. Appl. Environ. Microbiol. 51, 598603. 
Linkfield, T. G., Suflita, J. M. \& Tiedje, J. M. 1989 Characterization of the acclimation period before anaerobic dehalogenation of halobenzoates. Appl. Environ. Microbiol. 55, 27732778.

Madigan, M. T., Martinko, J. M. \& Parker, J. 1997 Biology of Microorganisms, 8th edition. Prentice Hall International, Upper Saddle River, NJ.

Moreno Andrade, I. \& Buitron, G. 2004 Variation of the microbial activity during the acclimation phase of a SBR system degrading 4 chlorophenol. Water Sci. Technol. 50(10), 251258.

Pessione, E., Bosco, F., Specchia, V. \& Giunta, C. 1996 Acinetobacter radioresistens metabolizing aromatic compounds. 1. Optimization of the operative conditions for phenol degradation. Microbios 88, 213221.

Rasmussen, L. D. \& Sørensen, S. J. 200I Effects of mercury contamination on the culturable heterotrophic, functional and genetic diversity of the bacterial community in soil. FEMS Microbiol. Ecol. 36, 19.

Rhine, E. D., Fuhrmann, J. J. \& Radosevich, M. 2003 Microbial community responses to atrazine exposure and nutrient availability: linking degradation capacity to community structure. Microbial. Ecol. 46, 145160.
Stephen, J. R., Chang, Y. J., Gan, Y. D., Peacock, A., Pfiffner, S. M., Barcelona, M. J., White, D. C. \& Macnaughton, S. J. 1999 Microbial characterization of a JP 4 fuel contaminated site using a combined lipid biomarker/polymerase chain reaction denaturing gradient gel electrophoresis (PCR DGGE) based approach. Environ. Microbiol. 1, 231241.

Stoffels, M., Amann, R., Ludwig, W., Hekmat, D. \& Schleifer, K. H. I998 Bacterial community dynamics during start up of a trickle bed bioreactor degrading aromatic compounds. Appl. Environ. Microbiol. 64, 930939.

Tellez, T. G., Nirmalakhandan, N. \& Gardea Torresdey, J. L. 2002 Performance evaluation of an activated sludge system for removing petroleum hydrocarbons from oilfield produced water. Adv. Environ. Res. 6, 455470.

Townsend, C. R., Begon, M. \& Harper, J. L. 2002 Essentials of Ecology, 2nd edition. Blackwell Publishing, Oxford, UK.

Zumstein, E., Moletta, R. \& Godon, J. J. 2000 Examination of two years of community dynamics in an anaerobic bioreactor using fluorescence polymerase chain reaction (PCR) single strand conformation polymorphism analysis. Environ. Microbiol. 2, 6978 . 